\title{
DETERMINING THE CORRELATION BETWEEN CENTRAL CORNEAL THICKNESS AND INTRAOCULAR PRESSURE IN A NORMAL INDIAN POPULATION
}

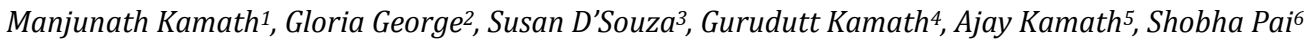 \\ 1 Professor, Department of Ophthalmology, Kasturba Medical College, Mangalore. \\ 2Junior Resident, Department of Ophthalmology, Kasturba Medical College, Mangalore. \\ ${ }^{3}$ Senior Resident, Department of Ophthalmology, Kasturba Medical College, Mangalore. \\ ${ }^{4}$ Professor, Department of Ophthalmology, Kasturba Medical College, Mangalore. \\ ${ }^{5}$ Associate Professor, Department of Ophthalmology, Kasturba Medical College, Mangalore. \\ ${ }^{6}$ Professor and HOD, Department of Ophthalmology, Kasturba Medical College, Mangalore.
}

ABSTRACT

\section{BACKGROUND}

The aim of this study was to evaluate the central corneal thickness over a cross section of a normal population in India and its correlation with intraocular pressure and various epidemiological factors.

\section{MATERIALS AND METHODS}

The CCT of 300 eyes of 150 normal patients of different age groups, attending the OPD were measured with anterior segment OCT. Intraocular pressure was measured using Goldmann Applanation Tonometry. The CCT was then compared with the patient's age, sex and IOP and its significance calculated.

\section{RESULTS}

The mean CCT was found to be 531.71 microns (+/-21.72) in RE and 532.62 microns (+/-21.71) in LE. The mean CCT among males was $540.3(+/-22.7)$ and among females $524.6(+/-17.3)$, the difference was statistically significant $(\mathrm{p}<0.05)$. The 16-30 age group had the highest mean CCT of 543.2 and the 61-75 age group had the lowest mean CCT of 515.6, the difference of which was significant $(\mathrm{p}<0.05)$. A significant positive correlation was found between the normal rage of IOP and CCT with around $0.9 \mathrm{~mm}$ of $\mathrm{Hg}$ increase in IOP for every 10-micron increase in CCT.

\section{CONCLUSION}

It was found that in normal subjects who had thicker corneas, IOP was higher as measured by Goldmann Applanation tonometry. The central corneal thickness was seen to vary with various epidemiological parameters as well in normal Indian population. Males were found to have significantly thicker corneas than females and the average CCT decreased significantly with increasing age.

\section{KEYWORDS}

Central Corneal Thickness, Intraocular Pressure, Goldmann Applanation Tonometry.

HOW TO CITE THIS ARTICLE: Kamath M, George G, D'Souza S, et al. Determining the correlation between central corneal thickness and intraocular pressure in a normal Indian population. J. Evolution Med. Dent. Sci. 2017;6(47):3619-3623, D0I: $10.14260 /$ Jemds/2017/780

\section{BACKGROUND}

Variability in innumerable measurable aspects is inherent to the human race and the accepted normal ranges of these aspects is subject to change as our knowledge of the human body steadily increases. The human eye is not an exception to this rule.

The measurement of central corneal thickness (CCT) has become a crucial step in the ophthalmic evaluation preceding keratorefractive surgery. Also, it has become increasingly important in the evaluation of patients with ocular hypertension and glaucomas.(1)

Age, gender and race are epidemiological parameters that are known to affect central corneal thickness. ${ }^{(2)}$

Financial or Other, Competing Interest: None.

Submission 01-05-2017, Peer Review 01-06-2017,

Acceptance 07-06-2017, Published 12-06-2017.

Corresponding Author:

Dr. Gloria George,

Thekkanath House, Thiruvanoth Lane,

Ayyanthole, Thrissur-680003, Kerala.

E-mail: glo.grg@gmail.com

DOI: $10.14260 /$ jemds $/ 2017 / 780$

\section{(c) $($ ) $९$}

These factors have scarcely been studied in the Indian population and hence it becomes important to evaluate the physiological changes that occur in the second largest population in the world.

Central corneal thickness, over the past few decades has gained tremendous importance in the management of glaucoma as it was observed that errors in the measurement of intraocular pressure was evident when patients who had high or low central corneal thickness. Goldmann Applanation tonometry has been considered to be the gold standard for determining IOP. Several other studies have shown that central corneal thickness affects the accuracy of applanation tonometry.(3),(4)

Optical Coherence Tomography is a technology that was developed recently and has advantages that it is non-invasive and non-contact. OCT was developed in the early 1990s and was available for ophthalmological practice in 1996. The first generation of OCT was called Time-Domain OCT or TD-OCT. The second-generation instrument was developed in 2000 and a third-generation instrument named Stratus OCT became available in 2002 which achieved increased speed in imaging and increased resolution. Later in the decade, Spectral Domain OCT came into wide practice.(5)(6) Several studies have proven that OCT is a non-invasive and accurate 
method for measuring Central Corneal Thickness and the results are easily reproducible.(7)

The aim of the present study was to compare the correlation in the Indian race, of central corneal thickness with age, sex and intraocular pressure.

Thus, through this study, we attempt to understand the pattern of changes in this valuable parameter i.e. central corneal thickness and thereby contribute to the existing pool of knowledge.

\section{MATERIALS AND METHODS}

This was a hospital based descriptive study conducted to compare the physiological patterns of variations in central corneal thickness based on intraocular pressure, age and gender.

It was conducted at Kasturba Medical College Hospital, Attavar and Government Wenlock Hospital, Mangalore, involving 300 eyes of 150 patients with study period being two years from October 2014 to August 2016. The sample size was calculated using assumed $r$ value 0.419 as determined by Doughty et al(8) by substituting in the formula $\mathrm{n}=\left[2\left(\mathrm{Z}_{\alpha}+\mathrm{Z}_{\beta}\right)^{2} / \mathrm{c}^{2}\right]+3$ (where $\mathrm{c}=0.5 \ln (1+\mathrm{r}) /(1-\mathrm{r}), \mathrm{Z}_{\alpha}=1.96$ at $95 \%$ confidence interval, $Z_{\beta}=1.28$ at $90 \%$ power). Study had clearance from institutional ethics committee and written informed consent was obtained. Normal individuals of various age groups and either sex with normal IOP attending Ophthalmology OPD were included in the study. Those with history of corneal degeneration or ulceration, anterior segment surgical procedures, glaucoma, diabetes mellitus, active conjunctivitis and subjects wearing contact lenses were excluded from the study. 150 patients were selected after ruling out the abovementioned exclusion criteria. They were divided into 6 groups based on age namely $0-15,16-30$, 31-45, 46-60, 61-75 and 76-90 with each group having 25 patients of both genders. A complete ophthalmological evaluation was done which included best corrected visual acuity, torchlight and slit-lamp examination which was followed by a fundus examination.

The patients then underwent evaluation of central corneal thickness using Cirrus SD-OCT which was followed by measurement of intraocular pressure using Goldmann Applanation Tonometry. Statistical data analysis was performed with SPSS for windows, version 9.0 using student's unpaired ' $\mathrm{t}$ ' test- $\mathrm{p}$ values lesser than 0.05 was considered significant. The correlation between central corneal thickness and intraocular pressure was determined through regression analysis.

\section{RESULTS}

Among the 150 patients, 76 patients were male, 74 patients were female. Average CCT in the Right eye was found to be $531.71 \mu \mathrm{m}$ and average CCT in the Left eye was found to be $532.6 \mu \mathrm{m}$.

The average CCT in the RE for females was found to be $523.32 \mu \mathrm{m}$ and average CCT in RE for males was found to be $539.87 \mu \mathrm{m}$. The average CCT in the LE for females was found to be $524.62 \mu \mathrm{m}$ and average CCT in LE for males was found to be $540.39 \mu \mathrm{m}$. The difference in CCT between males and females in both eyes was found to be statistically significant $(\mathrm{p}<0.05)$.

It was observed that the mean CCT in the right eye was highest in the 16-30 age group i.e. $543.20 \mu \mathrm{m}$ and lowest in the $61-75$ age group i.e. $515.60 \mu \mathrm{m}$. Similarly, it was observed that the mean CCT in the left eye was highest in the 16-30 age group i.e. 543.84 $\mu \mathrm{m}$ and lowest in the 61-75 age group i.e. $518.16 \mu \mathrm{m}$. A general decreasing trend was observed i.e. CCT was found to decrease by an average of $2.3 \mu \mathrm{m}$ for every decade which was statistically significant.

As it can be observed in the Figure 1, average CCT among males was found to be higher than females in all age groups. The largest difference between males and females was seen in the 76-90 age group in both eyes. All other age groups had similar and lesser differences in CCT among males and females, in both right and left eyes. The decreasing trend of CCT can also be observed upto 75 years of age among both sexes.

It was observed that with increasing central corneal thickness, intraocular pressure was also seen to rise, in both eyes, as can be seen in the Figure 2. The coefficient of correlation between IOP and CCT in both eyes was 0.8 which was statistically highly significant. This indicated a very strong positive correlation between IOP and CCT. Through regression analysis (Figure 2 and Figure 3 ) it was determined that for every 10-micron increase in CCT from the mean value, IOP increases by around $0.9 \mathrm{~mm}$ of $\mathrm{Hg}$.

The average IOP in the RE was found to be $13.41 \mathrm{~mm}$ of $\mathrm{Hg}$ and $\mathrm{LE}$ was $13.49 \mathrm{~mm}$ of $\mathrm{Hg}$, the difference between which was statistically insignificant. The variation of IOP with age was also noted, and a decreasing trend was observed, though this was also statistically insignificant.

\begin{tabular}{|c|c|c|c|c|c|c|c|}
\hline Investigators & $\begin{array}{c}\text { Race/ } \\
\text { Ethnicities }\end{array}$ & Methods & $\begin{array}{c}\text { No. of } \\
\text { Subjects/Eyes }\end{array}$ & Age & Gender & $\begin{array}{c}\text { CCT } \\
(\mu \mathrm{m})\end{array}$ & $\begin{array}{c}\text { IOP } \\
(\mathrm{mm} \text { of } \mathrm{Hg})\end{array}$ \\
\hline $\begin{array}{l}\text { La Rosa } \\
\text { et al(9) }\end{array}$ & Caucasian & $\begin{array}{c}\text { Ultrasonic } \\
\text { pachymetry }\end{array}$ & 51 & 65.2 & $\mathrm{~N} / \mathrm{A}$ & 555.9 & 15.6 \\
\hline $\begin{array}{c}\text { Hahn } \\
\text { et al(10) }\end{array}$ & Latino & $\begin{array}{c}\text { Ultrasonic } \\
\text { pachymetry }\end{array}$ & $\begin{array}{c}1578 \\
634 \\
944 \\
\end{array}$ & $\mathrm{~N} / \mathrm{A}$ & $\begin{array}{c}\mathrm{M}+\mathrm{F} \\
\mathrm{M} \\
\mathrm{F}\end{array}$ & $\begin{array}{l}546.5 \\
549.3 \\
544.7 \\
\end{array}$ & $>10$ \\
\hline $\begin{array}{l}\text { Casson } \\
\text { et al(11) }\end{array}$ & Burmese & $\begin{array}{c}\text { Ultrasonic } \\
\text { pachymetry }\end{array}$ & $\begin{array}{c}1909 \\
756 \\
1153\end{array}$ & 56.2 & $\begin{array}{c}\mathrm{M}+\mathrm{F} \\
\mathrm{M} \\
\mathrm{F}\end{array}$ & $\begin{array}{c}521.9 \\
522 \\
521.9\end{array}$ & 14.5 \\
\hline $\begin{array}{l}\text { Wong } \\
\text { et al(12) }\end{array}$ & Chinese & $\begin{array}{c}\text { Ultrasonic } \\
\text { pachymetry }\end{array}$ & 17 & 65.5 & M & 554 & $\mathrm{~N} / \mathrm{A}$ \\
\hline $\begin{array}{l}\text { Aghaian } \\
\text { et al(2) }\end{array}$ & $\begin{array}{c}\text { African-American } \\
\text { Caucasian } \\
\text { Chinese }\end{array}$ & $\begin{array}{l}\text { Ultrasonic } \\
\text { pachymetry }\end{array}$ & $\begin{array}{l}26 \\
36 \\
41\end{array}$ & $\mathrm{~N} / \mathrm{A}$ & $\begin{array}{l}M+F \\
M+F \\
M+F\end{array}$ & $\begin{array}{l}524.8 \\
562.8 \\
569.5\end{array}$ & $\mathrm{~N} / \mathrm{A}$ \\
\hline
\end{tabular}




\begin{tabular}{|c|c|c|c|c|c|c|c|}
\hline & $\begin{array}{l}\text { Filipino } \\
\text { Hispanic } \\
\text { Japanese }\end{array}$ & & $\begin{array}{l}33 \\
27 \\
38\end{array}$ & & $\begin{array}{l}M+F \\
M+F \\
M+F\end{array}$ & $\begin{array}{c}559 \\
563.6 \\
538.5\end{array}$ & \\
\hline $\begin{array}{l}\text { Shimmyo } \\
\text { et al(13) }\end{array}$ & $\begin{array}{c}\text { African-American } \\
\text { Asian } \\
\text { Caucasian } \\
\text { Hispanic }\end{array}$ & $\begin{array}{c}\text { Ultrasonic } \\
\text { pachymetry }\end{array}$ & $\begin{array}{c}118 \\
172 \\
1482 \\
204\end{array}$ & $\begin{array}{c}37.2 \\
38.8 \\
38 \\
34.2\end{array}$ & $\begin{array}{l}\mathrm{M}+\mathrm{F} \\
\mathrm{M}+\mathrm{F} \\
\mathrm{M}+\mathrm{F} \\
\mathrm{M}+\mathrm{F}\end{array}$ & $\begin{array}{l}535.4 \\
549.7 \\
552.5 \\
551.1\end{array}$ & $\begin{array}{l}14.9 \\
14.7 \\
14.8 \\
15.2\end{array}$ \\
\hline $\begin{array}{l}\text { Durkin } \\
\text { et al(14) }\end{array}$ & $\begin{array}{l}\text { Australian } \\
\text { Aboriginal } \\
\text { Caucasian }\end{array}$ & $\begin{array}{l}\text { Ultrasonic } \\
\text { pachymetry }\end{array}$ & $\begin{array}{c}80 \\
109 \\
51 \\
64\end{array}$ & $\begin{array}{l}44.8 \\
47.2\end{array}$ & $\begin{array}{l}\mathrm{M} \\
\mathrm{F} \\
\mathrm{M} \\
\mathrm{F}\end{array}$ & $\begin{array}{l}515.8 \\
514.4 \\
542.6 \\
546.3\end{array}$ & $\mathrm{~N} / \mathrm{A}$ \\
\hline $\begin{array}{l}\text { Iyamu and } \\
\text { Osubeni(15) }\end{array}$ & African & $\begin{array}{c}\text { Ultrasonic } \\
\text { pachymetry }\end{array}$ & $\begin{array}{l}77 \\
53\end{array}$ & $\begin{array}{l}48.2 \\
47.1\end{array}$ & $\begin{array}{l}\mathrm{M} \\
\mathrm{F}\end{array}$ & $\begin{array}{l}551 \\
546\end{array}$ & $\begin{array}{l}15.23 \\
16.15\end{array}$ \\
\hline $\begin{array}{l}\text { Nangia } \\
\text { et al(16) }\end{array}$ & Indian & $\begin{array}{c}\text { Ultrasonic } \\
\text { pachymetry }\end{array}$ & 4612 & 49.1 & $\mathrm{M}+\mathrm{F}$ & 514 & 13.63 \\
\hline $\begin{array}{l}\text { Vijaya } \\
\text { et al(17) }\end{array}$ & Indian & $\begin{array}{c}\text { Ultrasonic } \\
\text { pachymeter }\end{array}$ & $\begin{array}{l}3020 \\
3734\end{array}$ & 55.2 & $\begin{array}{l}M \\
F\end{array}$ & $\begin{array}{c}515.6 \\
508\end{array}$ & $14.29(\mathrm{M}+\mathrm{F})$ \\
\hline
\end{tabular}

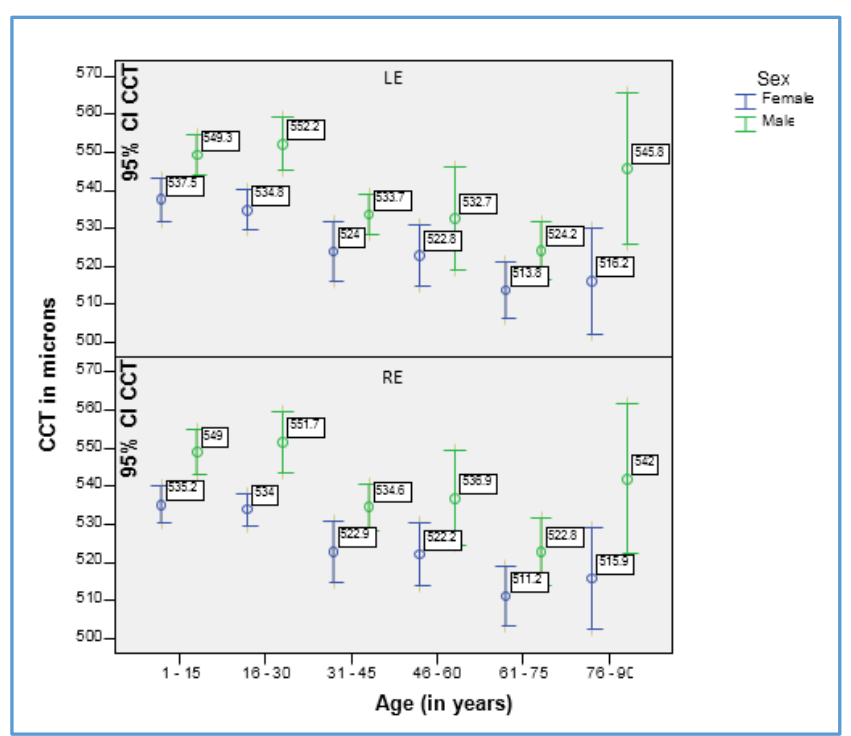

Figure 1. Correlation between Age and CCT in $R E$ and $L E$ males and females

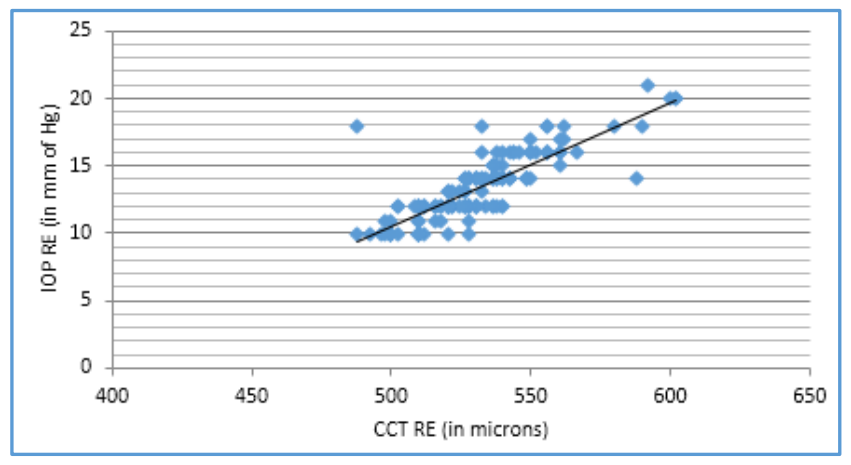

Figure 2. Scatter plot showing the correlation of CCT-RE and IOP-RE of in all the participants with $95 \%$ confidence interval of the regression line. $\left(R^{2}=0.683, r=0.826, p<\right.$ $0.05)$. The regression line shows IOP $=0.091 \mathrm{CCT}-35.30$

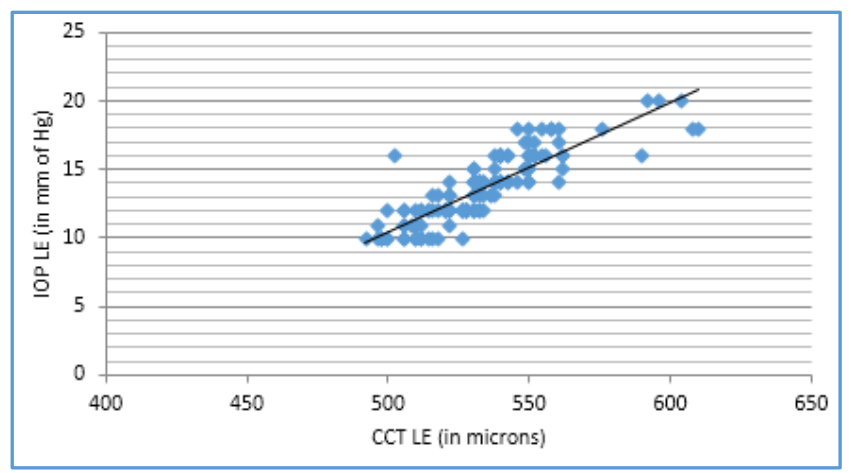

Figure 3. Scatter plot showing the correlation of CCT-LE and IOP-LE of in all the participants with $95 \%$ confidence interval of the regression line. $\left(R^{2}=0.732, r=0.855, p<\right.$ 0.05). The regression line shows IOP $=0.094$ CCT -36.98

\section{DISCUSSION}

Several studies have been done around the world in various ethnic groups to study the relationship between central corneal thickness and certain epidemiological parameters as can be seen in Table 1.

In our study, 300 eyes of 150 normal patients were studied, of which 76 were male and 74 were female. The average CCT in the right eye was found to be $531.71 \mu \mathrm{m}$ and average CCT in the left eye was found to be $532.61 \mu \mathrm{m}$. This result is significantly higher than the average CCT among Indian population as provided by Nangia et al(16) which was $514.33 \mu \mathrm{m}$, and Vijaya et al(17) which was $511.43 \mu \mathrm{m}$. However, this result was comparable to the $537 \mu \mathrm{m}$ in the Rotterdam Study(18) and $527 \mu \mathrm{m}$ in the Icelandic Reykjavik Eye Study(19) but considerably lower than $556 \mu \mathrm{m}$ in the Beijing Eye Study ${ }^{(20)}$ and the $541 \mu \mathrm{m}$ in the Singapore-Malay Eye Study.(21) Also as was seen in Table 1, the value we obtained was significantly higher than the value obtained by Durkin et al(14) i.e. $515 \mu \mathrm{m}$ among the Australian population.

Both previous studies done in the Indian population used ultrasonic pachymetry whereas our study used anterior segment OCT. Ultrasound pachymetry is known to produce 
relatively lesser corneal thickness measurement(22) which may explain the difference obtained among the mean CCT values.

In our study, the difference in CCT between males and females in both eyes was found to be statistically significant i.e. males had significantly thicker corneas than females.

Both Nangia et al(16) and Vijaya et al(17) found similar results, wherein central corneal thickness was associated significantly with male gender.

A general decreasing trend was observed i.e. with increase in age, CCT was found to gradually decrease and it was found to be statistically significant. CCT was found to decrease by an average of $2.3 \mu \mathrm{m}$ for every decade. Vijaya et $\mathrm{al}^{(17)}$ and Nangia et al(16) also described a similar trend of decreasing CCT with increasing age. Results by Vijaya et al described a 2.4 decrease in CCT for urban population and $4.34 \mu \mathrm{m}$ in urban population for each decade. A meta-analysis study by Doughty et al(23) also described a similar decrease in CCT with age but of borderline significance. Several other studies have also described a decreasing trend. $(24,15)$

In our study, the average IOP was found to be $13.4 \mathrm{~mm}$ of Hg which is comparable to the value obtained by Nangia et al i.e. $13.6 \mathrm{~mm}$ of $\mathrm{Hg}$ and Vijaya et al which was $14.3 \mathrm{~mm}$ of $\mathrm{Hg}$. We could demonstrate a decrease in IOP with age but this decrease was insignificant.

Several studies have demonstrated the positive correlation between intra-ocular pressure measurement by Goldmann Applanation Tonometry and Central Corneal Thickness. In this study too, we observed a similar trend of increasing IOP with increasing CCT. Coefficient of correlation between IOP and CCT was 0.8, which was statistically significant. Through regression analysis, it was determined that for every 10-micron increase in CCT, the intraocular pressure was seen to rise by $0.9 \mathrm{~mm}$ of $\mathrm{Hg}$.

In contrast to our results, the study by Vijaya et al(17) demonstrated a $0.24 \mathrm{~mm}$ of $\mathrm{Hg}$ increase and Nangia et al (16) demonstrated $0.2 \mathrm{~mm}$ of $\mathrm{Hg}$ increase in IOP for every 10 microns of CCT. Our values were closer to the results demonstrated by Ehler et al(4) where the IOP was found to increase by $0.7 \mathrm{~mm}$ of $\mathrm{Hg}$ for every 10-micron increase in central corneal thickness.

Hence, it is necessary to complement these findings with more studies in order to set a baseline for application of a correction factor in the measurement of intraocular pressure by Goldmann Applanation Tonometry.

\section{CONCLUSION}

Central corneal thickness of 150 patients were measured and compared with various demographic criteria. We could demonstrate a positive correlation between central corneal thickness and intraocular pressure as measured by Goldmann Applanation Tonometry i.e. an increase in IOP by $0.9 \mathrm{~mm}$ of $\mathrm{Hg}$ for every 10-micron increase in CCT, which was higher than the values obtained in other similar studies done in Indian population. It was found that central corneal thickness was higher among men than women i.e. males had thicker corneas than females which was statistically significant, but this may not achieve clinical significance.

Central corneal thickness was also found to decrease with age, i.e. for every decade, CCT was found to decrease by 2.3 microns.
Limitations of the study were that the sample size was relatively small $(n=150)$, therefore the results of the study cannot be generalised to the whole population. Hence, studies with larger population group are needed.

This study contributes to the limited pool of knowledge about central corneal thickness in a normal Indian population. More studies and research is warranted in this area as central corneal thickness is an important diagnostic criterion for evaluation of the spectrum of glaucoma as well as for keratorefractive surgery.

\section{REFERENCES}

[1] Migilor S, Albe E, Guareshi M, et al. Intraobserver and interobserver reproducibility in the evaluation of ultrasonic pachymetry measurements of central corneal thickness. Br J Ophthalmol 2004;88(2):174-7.

[2] Aghaian E, Choe JE, Lin S, et al. Central corneal thickness of Caucasians, Chinese, Hispanics, Filipinos, African Americans, and Japanese in a glaucoma clinic. Ophthalmology 2004;111(12):2211-9.

[3] Copt RP, Thomas R, Mermoud A. Corneal thickness in ocular hypertension, primary open-angle glaucoma, and normal tension glaucoma. Arch Ophthalmol 1999;117(1):14-6.

[4] Ehlers N, Bramsen T, Sperling S. Applanation tonometry and central corneal thickness. Acta Ophthalmol 1975;53(1):34-43.

[5] Huang D, Swanson EL, Lin CP, et al. Optical coherence tomography. Science 1991;254(5035):1178-81.

[6] Schumann JS, Hee MR, Arya AV, et al. Optical coherence tomography: a new tool for glaucoma diagnosis. Curr Opin Ophthalmol 1995;6(2):89-95.

[7] Fishman GR, Pons ME, Seedor JA, et al. Assessment of central corneal thickness using optical coherence tomography. J Cataract Refract Surg 2005;31(4): 707-11.

[8] Doughty MJ, Zaman ML. Human corneal thickness and its impact on intraocular pressure measures: a review and meta-analysis approach. Surv Ophthalmol 2000;44(5):367-408.

[9] Rosa FA La, Gross RL, Orengo-Nania S. Central corneal thickness of Caucasians and African Americans in glaucomatous and non-glaucomatous populations. Arch Ophthalmol 2001;119(1):23-7.

[10] Hahn S, Azen S, Ying-Lai M, et al. Central corneal thickness in Latinos. Invest Ophthalmol Vis Sci 2003;44(4):1508-12.

[11] Casson RJ, Abraham LM, Newland HS, et al. Corneal thickness and intraocular pressure in a nonglaucomatous Burmese population: the Meiktila eye study. Arch Ophthalmol 2008;126(7):981-5.

[12] Wong TT, Wong TY, Foster PJ, et al. The relationship of intraocular pressure with age, systolic blood pressure, and central corneal thickness in an Asian population. Invest Ophthalmol Vis Sci 2009;50(9):4097-102.

[13] Shimmyo M. Intraocular pressure, Goldmann applanation tension, corneal thickness, and corneal curvature in Caucasians, Asians, Hispanics, and African Americans. Am J Ophthalmol 2003;137(6):1170. 
[14] Durkin SR, Tan EW, Casson RJ, et al. Central corneal thickness among Aboriginal people attending eye clinics in remote South Australia. Clin Experiment Ophthalmol 2007;35(8):728-32.

[15] Iyamu E, Osuobeni E. Age, gender, corneal diameter, corneal curvature and central corneal thickness in Nigerians with normal intra ocular pressure. J Optom 2012;5(2):87-97.

[16] Nangia V, Jonas JB, Sinha A, et al. Central corneal thickness and its association with ocular and general parameters in Indians: the central India eye and medical study. Ophthalmology 2010;117(4):705-10.

[17] Vijaya L, George R, Arvind H, et al. Central corneal thickness in adult South Indians: the Chennai glaucoma study. Ophthalmology 2010;117(4):700-4.

[18] Wolfs RC, Klaver CC, Vingerling JR, et al. Distribution of central corneal thickness and its association with intraocular pressure: the Rotterdam study. Am J Ophthalmol 1997;123(6):767-72.

[19] Eysteinsson T, Jonasson F, Sasaki H, et al. Central corneal thickness, radius of the corneal curvature and intraocular pressure in normal subjects using noncontact techniques: Reykjavik eye study. Acta Ophthalmol Scand 2002;80(1):11-5.
[20] Jonas JB, Xu L, Wang YX. The Beijing eye study. Acta Ophthalmol 2009;87(3):247-61.

[21] Foong AW, Saw SM, Loo JL, et al. Rationale and methodology for a population-based study of eye diseases in Malay people: the Singapore Malay eye study (SiMES). Ophthalmic Epidemiol 2007;14(1): 25-35.

[22] Leung DY, Lam DK, Yeung BY, et al. Comparison between central corneal thickness measurements by ultrasound pachymetry and optical coherence tomography. Clin Exp Ophthalmol 2006;34(8):751-4.

[23] Doughty MJ, Laiquzzaman M, Muller A, et al. Central corneal thickness in European (white) individuals, especially children and the elderly, and assessment of its possible importance in clinical measures of intraocular pressure. Ophthalmic Physiol Opt 2002;22(6):491-504.

[24] Prasad A, Fry K, Hersh PS. Relationship of age and refraction to central corneal thickness. Cornea 2011;30(5):553-5. 